\title{
TO STUDY THE PREVALENCE OF DIABETIC RETINOPATHY IN DIABETES MELLITUS PATIENTS AND ITS CORRELATION WITH VARIOUS ASSOCIATED RISK FACTORS
}

\author{
Sanjay Kai ${ }^{1}$, Shiffali Sarngal2 ${ }^{2}$ Sharika Ganjoo ${ }^{3}$ \\ ${ }_{1}^{1}$ Assistant Professor, Department of Ophthalmology, Government Medical College, Jammu. \\ ${ }^{2}$ Demonstrator, Department of Forensic Medicine, Government Medical College, Jammu. \\ ${ }^{3}$ Post Graduate, Department of Ophthalmology, Government Medical College, Jammu.
}

\section{ABSTRACT}

Diabetic retinopathy is a microangiopathy primarily affecting pre-capillary venules, although larger vessels may also be involved. Retinopathy exhibits features of both microvascular occulusion and leakage. Diabetic maculopathy is the most common cause of visual impairment in diabetic patients.

\section{AIMS}

To asses the prevalence of Diabetic Retinopathy (DR) in diabetic patients.

To find the correlation of diabetic retinopathy with various risk factors.

\section{SETTING AND DESIGN}

Hospital based prospective study.

\section{MATERIALS AND METHODS}

Detailed history with visual acuity, slit lamp examination, fundus examination, IOP and Gonioscopy were recorded.

\section{INVESTIGATIONS}

Blood sugar (F) and (PP), Lipid profile, Hb1ac.

\section{STATISTICAL ANALYSIS}

Chi-square test and Fisher exact test. Crude Odds' ratio for strength of association.

\section{RESULTS}

- Prevalence of DR was found to be 72\%: NPDR (59.3\%), PDR (5.4\%) and maculopathy (7.3\%).

- Chances of retinopathy were found to be more with increased duration of diabetes.

- Males were found to have more chances of developing retinopathy.

- No significant association with increased IOP, hypertension or altered lipid profile was found.

\section{CONCLUSION}

Diabetic retinopathy risk in diabetic patients depends on age, sex, duration of diabetes, blood sugar (F) levels, altered renal function and also on types of diabetes.

\section{KEYWORDS}

Diabetic Retinopathy, Diabetic Maculopathy, Diabetic Retinopathy Prevelance, NIIDM, IDDM.

HOW TO CITE THIS ARTICLE: Sanjay Kai, Shiffali Sarngal, Sharika Ganjoo. "To Study the Prevalence of Diabetic Retinopathy in Diabetes Mellitus Patients and its Correlation with Various Associated Risk Factors." Journal of Evolution of Medical and Dental Sciences 2015; Vol. 4, Issue 98, December 07; Page: 16341-16346, DOI: 10.14260/jemds/2015/2414

\section{INTRODUCTION}

Diabetes Mellitus, a disorder of carbohydrate metabolism characterized primarily by hyperglycaemia and glycosuria with secondary anomalies of the metabolism of proteins and fats. Diabetes may be insulin dependent (Type 1 IDDM) or noninsulin dependent (Type 2 NIDDM) diabetes mellitus; $90 \%$ to $95 \%$ of patients with diabetes have type 2 diabetes. Because of the disproportionately large number of patients with type 2 diabetes, this group comprises a substantial proportion of patients with visual impairment secondary to diabetic retinopathy, even though type 1 diabetes is associated with more frequent and more severe ocular complications.

Financial or Other, Competing Interest: None.

Submission 16-11-2015, Peer Review 17-11-2015,

Acceptance 30-11-2015, Published 05-12-2015.

Corresponding Author:

Sanjay Kai,

H.No. 39, Canal Road, Rajinder Nagar,

Jammu, $J$ \& $K$.

E-mail: drsanjaykai@gmail.com

DOI:10.14260/jemds/2015/2414
The crude prevalence of diabetes in urban India is $9 \%$ and in rural India is 3\% of the total population.

\section{CLASSIFICATION OF DIABETIC RETINOPATHY}

The ETDRS (1991).(1) has classified diabetic retinopathy into non-proliferative (NPDR) and proliferative retinopathy (PDR).

\section{A) NON-PROLIFERATIVE DIABETIC RETINOPATHY}
a) NPDR.
b) Moderate NPDR.
c) Severe NPDR.
d) Very severe NPDR.

\section{B) PROLIFERATIVE DIABETIC RETINOPATHY}
a) Early PDR.
b) High risk PDR.
c) Advanced PDR. 


\section{DIABETIC MACULOPATHY}

ETDRS (1991).(1) Study defined maculopathy as "Clinically significant macular edema" if it has any of the following characteristics:

1. Retinal oedema at or within 500 microns from fovea.

2. Exudates at or within 500 microns from fovea with thickening of the adjacent retina.

3. Thickening larger than 1 disc area and a part of it if located within 1 disc diameter of the centre of macula.

\section{PREVALANCE OF DIABETIC RETINOPATHY}

As per WESDR (1991) at 20 years of duration of diabetes mellitus about $99 \%$ with type 1 and $60 \%$ with type 2 DM have some retinopathy.

Type 1DM- no clinically apparent retinopathy in first 5 years.

5 to 10 years- $>25$ to $30 \%$ have some retinopathy.

10 to 15 years- $>75$ to $95 \%$ have some retinopathy.

Type 2 DM- NPDR: 23\%- 11 to 13 years.

$60 \%$ (16 years).

India has 50 million diabetics as per WHO estimates. The prevalence of Diabetic retinopathy in NIDDM was 34\% and $37.1 \%$ in two studies conducted in South India.

In Andhra Pradesh, eye diseases study of self-reported diabetic's prevalence was $22.4 \%$. In the Chennai Urban Rural Epidemiologic Study (CURES), an urban sample the estimated overall prevalence was $17.6 \%$. There was no study from our region, which had documented the prevalence of diabetic retinopathy in patients of diabetes mellitus so we decided to conduct this study.

\section{MATERIAL AND METHODS}

The proposed study was conducted on 150 diagnosed cases of Diabetes mellitus attending Eye OPD for ocular examination at the Upgraded Department of Ophthalmology, Government Medical College, Jammu. The cases were selected at random and enrolled in the study.

\section{EXCLUSION CRITERIA}

1. Hazy media.

2. Gestational Diabetes Mellitus.

3. Patients on systemic steroids.

\section{OCULAR EXAMINATION}

Best corrected visual acuity for distance and near both were recorded. Intraocular pressure was documented. Dilated fundus examination of both eyes was done using direct ophthalmoscope, posterior pole of the retina and macula examination was done with slit lamp biomicroscopy. Any changes attributable to diabetes were documented as per ETDRS classification.

\section{BIOCHEMICAL INVESTIGATIONS}

1. Blood sugar (F).

2. Blood sugar (PP).

3. Serum urea.

4. Serum creatinine.

5. Serum electrolytes.

6. Lipid profile estimation.

\section{RESULTS}

The age wise distribution of the patients in various age group is given in Table 1. P-value 0.93 (Statistically insignificant). The distribution of diabetic patients with or without retinopathy according to sex is given in Table 2 . Crude Odds ratio is 2.99 that is males have 2.99 times more chances of developing retinopathy. P-value 0.002 (Highly significant).

The distribution of patients with or without diabetic retinopathy according to duration of diabetes is given in Table 3. P-value 0.000 (Highly significant), thus chances of retinopathy increase with the increase in duration of diabetic retinopathy. The distribution of diabetic patients with or without retinopathy according to measurement of intraocular pressure is given in Table 4. P-value 0.56 (Statistically not significant).

The distribution of diabetic patients with or without diabetic retinopathy according to type of diabetes is given in Table 5. P-value 0.03 (Statistically significant), thus patients with type I diabetes have more chances of developing retinopathy. The distribution of diabetic patients with or without retinopathy according to the level of fasting blood glucose is given in Table 6. P-value 0.0001 (Highly statistically significant), thus patients with blood glucose (Fasting) more than $126 \mathrm{mg} \%$ have more chances of developing retinopathy.

The distribution of diabetic patients with or without retinopathy according to presence of associated hypertension is given in Table 7. P-value 0.45 (Statistically not significant). The distribution of diabetic patients with or without retinopathy according to presence of altered renal function is given in Table 8. P-value 0.0008 (Statistically highly significant), thus patients with altered renal function have more chances of developing retinopathy.

The distribution of diabetic patients with or without retinopathy according to presence of altered lipid profile is given in Table 9. P-value 0.18 (Statistically not significant).

The distribution of NPDR, PDR and maculopathy among the diabetic retinopathy patients according to duration of diabetes is given in Table 10. Thus out of 108 diabetic retinopathy patients, $82.5 \%(89 / 108)$ had NPDR, $7.5 \%$ $(8 / 108)$ had PDR and $10 \%(11 / 108)$ had maculopathy.

\section{DISCUSSION}

In our study out of 150 diabetics who attended eye OPD 108 had some retinopathy, thus overall prevalence was $72 \%$. Out of 108 patients with diabetic retinopathy 89 patients had NPDR (59.3\%), 8 patients had PDR (5.4\%) and 11 patients had Maculopathy (7.3\%). Qoqonokana MQ et al.(2) (2010) did a hospital based study on 50 diabetes mellitus patients attending eye OPD and found the prevalence of diabetic retinopathy to be $86 \%$ with $76 \%$ NPDR and $10 \%$ PDR.

Jain IS.(3) (1988) found that the prevalence of diabetic retinopathy was $42.9 \%$ in his study on diabetic subjects. Jost BS et al.(4) (2010) in a study on type 2 DM patients found the prevalence of diabetic retinopathy to be $38.4 \%$ and also established a direct relation between diabetic retinopathy and duration of diabetes mellitus, renal damage and levels of glycosylated haemoglobin $\%$.

Javadi MA et al.(5) (2009) in their study on 759 diabetics with 639 undergoing eye examination found that 240 patients had some retinopathy. Overall prevalence was $37.5 \%$ with $27.3 \%$ NPDR and $9.6 \%$ PDR. The higher prevalence of diabetic retinopathy in our study could be due to the fact that ours is a hospital based study, in which diabetic patients attending eye OPD for their ophthalmologic check-up were taken into consideration.

In our study, it was found that no patient with duration of diabetes less than 5 years had retinopathy, 73 patients $(67 \%$ of those with retinopathy) were with duration of diabetes between 12-21 years.

Yanko L et al.(6) (1983) found that there was no evidence of retinopathy in diabetics with duration of diabetes less than 5 years and they also reported that highest prevalence of diabetic retinopathy among diabetics was with duration of diabetes more than 10 years (79.4\%). Kim CH et al.(7) (1998) in their study on type $2 \mathrm{DM}$ subjects found that mean duration of diabetes in subjects with retinopathy was $11.0 \pm 0.3$ years as compared to $5.6 \pm 0.3$ years in diabetics without retinopathy, difference being statistically significant $(p<0.05)$. 
Agrawal RP et al.(8) (2001) found a strong association between prevalence of diabetic retinopathy and duration of diabetes mellitus, body mass index, glycaemic control and dyslipidemia in type $1 \mathrm{DM}$ patients. The results in our study were similar to that of other authors that is chances of retinopathy are more with increased duration of diabetes.

In our study, $65 \%$ of patients with retinopathy are males and $35 \%$ of patients with retinopathy are females.

Bajpai HS et al.(9) (1979) in his study on 110 diabetic retinopathy patients found that out of 110 patients $61.5 \%$ were males and 38.5\% females. Rema M et al.(10) (2005) found that prevalence of diabetic retinopathy was significantly higher in males than in females $21.3 \%$ in males and $14.6 \%$ in females, $\mathrm{p}<0.0001$ ). The observations in our study are similar to that of other authors, thus males have more chances of developing retinopathy, $\mathrm{p}<0.002$ (Statistically significant).

In our study, we did not find any statistically significant association between intraocular pressure and diabetic retinopathy.

Christiansson J.(11) (1961) found that higher Intraocular Pressure (IOP) has some role in delaying diabetic retinopathy changes. Mooney AJ.(12) (1963) found that higher IOP has some role in delaying and preventing the development of retinopathy changes. In our study, $73 \%$ had blood glucose (Fasting) levels more than $126 \mathrm{mg} \%$ and $27 \%$ had levels less than $126 \mathrm{mg} \%$.

Van Leiden HA et al.(13)(2002) in their study found that $7 \%$ of patients with retinopathy had normal glucose metabolism, $11 \%$ of patients had impaired glucose metabolism and $34 \%$ of patients with retinopathy were known cases of diabetes mellitus. Thus our study is similar to that of other authors and according to our study patients with higher blood glucose (Fasting) have more chances of developing retinopathy, $\mathrm{p}<0.0001$ (Statistically significant). In our study, $29 \%$ patients had associated hypertension and $71 \%$ had no hypertension with diabetes mellitus which was statistically insignificant.

Ballantyne DJ et al.(14) (1943) found that hypertension was associated in $50 \%$ of diabetics showing some retinopathy. Bajpai et al.(9) (1979) found that hypertension was associated with retinopathy in $31.4 \%$ of patients. In our study we did not find any statistically significant association between serum lipid level and diabetic retinopathy. Chew EY et al.(15) (1996) found that elevated serum lipids are associated with an increased risk of retinal hard exudates in persons with diabetic retinopathy.

Chopra R et al.(16) (2007) found that average Lp(a) levels in patients with diabetic retinopathy was $(68.5 \mathrm{mg} \%)$ significantly higher than in patients with no retinopathy (25.1mg\%), $\mathrm{p}<0.001$.

\section{CONCLUSION}

- Out of 150 diagnosed cases of diabetes mellitus, 108 had retinopathy, thus prevalence was $72 \%$.

- The males were more at risk of developing diabetic retinopathy as compare to females. P-value $=0.002$ (Highly significant).

- There was very less risk of developing diabetic retinopathy in first five years of disease duration. P-value $=0.000$ (Highly significant).

- Majority of patients with retinopathy had type 2 DM (90\%) as compared to type $1 \mathrm{DM}(10 \%)$, p-value $=0.03$ (Statistically significant).

- No statistically significant association of intraocular pressure, altered lipid profile, and hypertension was found with the diabetic retinopathy.
- Maximum number of patients with diabetic retinopathy had blood glucose (Fasting) levels more than $126 \mathrm{mg} \%$ $(73 \%)$ patients, $p$ - value $=0.0001$ (Highly significant) .

- Although only $22 \%$ of patients with retinopathy had altered renal function, but all the patients with altered renal function had some retinopathy, $\mathrm{p}$-value $=0.0008$ (Highly significant).

- In the present study out of $72 \%$ patients with some retinopathy, $59.3 \%$ were having Non-Proliferative Diabetic Retinopathy (NPDR), 5.4\% were having Proliferative Diabetic Retinopathy (PDR) and 7.3\% patients had maculopathy.

Thus according to our study, it was concluded that diabetic retinopathy chances in diabetic patients are dependent on risk factors and like age, sex, duration of diabetes, blood sugar fasting levels, altered renal functions and also type of diabetes.

\section{REFERENCES}

1. Early Treatment Diabetic Retinopathy Study Research Group (ETDRS) Report Number 10. Grading diabetic retinopathy from stereoscopic colour fundus photograph-an extension of the modified Airlie House Classification. Ophthalmology 1991;98:786-806.

2. Qoqonokana MQ, Brian G, Ramke J, Garcia J, Szetu J. Diabetic retinopathy in a hospital eye clinic in Soloman islands. Clin Experiment Ophthalmol 2010;38(9):862-6.

3. Jain IS. Vision threatening diabetic retinopathy. Ind J Ophthalmol 1988;36(1):3.

4. Jost BS, Hilgemberg E, Rodrigues EB, Danoitti AF, Bonamigo EL. Prevalance of diabetic retinopathy in type 2 DM in the city of Luzarna Arg Bras Oftalmol 2010;73(3):259-65.

5. Javadi MA, Katibeh M, Rafati F, Dehghan MH, Zayeri F, Yaseri $M$, et al. Prevalence of diabetic retinopathy in Tehran province-Population based study. BMC Ophthalmology 2009;9:1471-2415.

6. Yanko L, Goldbourt U, Michaelson IC, Shapiro A, Yaari S. Prevalence and 15 year incidence of retinopathy and associated characteristics in middle-aged and elderly diabetic men. Br J Ophthalmol 1983;67(11):759-65.

7. Kim CH, Hong SK, Park HJ, Yoon YH, Park JY, Lee UK. High serum lipoprotein (a) levels in Korean type 2 diabetes patients with proliferative diabetic retinopathy. Diabetes Care 1998;21(12):2149-51.

8. Agrawal RP, Singla M, Vyas SP, Hussain S, Jain GC, Kochar DR. Prevalence of retinopathy and its relation with various risk factors in type 1 Diabetes Mellitus-Hospital based study. Int J Diab Dev Countries 2001;21(4):18490.

9. Bajpai HS, Mehra KS, Singh VP, Tikko SK, Agrawal JK, Sharma A. Diabetic retinopathy: A clinico-biochemical study. Ind J Ophthalmol 1979;27(3):12-15.

10. Rema M, PremKumar S, Anitha B, Deepa R, Pradeepa R, Mohan V. Prevalence of diabetic retinopathy in urban India: The Chennai Urban Rural Epidemiology Study(CURES) Eye Study 1. Invest Ophthalmol Vis Sci 2005;46(7):2328-33.

11. Christiansson J. Intraocular pressure in diabetes mellitus. Acta Ophthal 1961;39:155-67.

12. Mooney AJ. Diabetic Retinopathy-A challenge. Br J Ophthalmol 1963;47:513-20.

13. Van Leiden HA, Dekker JM, Moll AC, Nijpels G, Heine RJ, Bouter LM, et al. Blood pressure, lipids and obesity are associated with retinopathy. Diabetes Care 2002;25:1320-25. 
14. Ballantyne DJ, Lowenstein A. The pathology of diabetic retinopathy. Trans Ophthalmol Soc UK 1943;63:95-113.

15. Chew EY, Klein ML, Ferris FL, Remaley NA, Murphy RP, Chantry K, et al. Association of elevated serum lipid levels with retinal hard exudates in diabetic retinopathy. ETDRS Report 22. Arch Ophthalmol 1996;144:1079-84.

16. Chopra R, Saramma JG, Mary J, Rebecca A. Lipoprotein (a) as a risk factor for diabetic retinopathy in patients with type 2 diabetes mellitus. Ind J Ophthalmol 2007;55(3):195-98.

\begin{tabular}{|c|c|c|c|c|}
\hline \multirow{3}{*}{$\begin{array}{l}\text { Age Group } \\
\text { (In years) }\end{array}$} & \multicolumn{2}{|c|}{ Diabetic Retinopathy } & \multirow{3}{*}{$\begin{array}{l}\text { Crude } \\
\text { Odds' } \\
\text { Ratio } \\
\end{array}$} & \multirow{3}{*}{$\begin{array}{c}95 \% \\
\text { Confidence } \\
\text { Interval } \\
\end{array}$} \\
\hline & Absent & Present & & \\
\hline & No. (\%) & No. (\%) & & \\
\hline $31-40$ & $6(14)$ & $16(15)$ & \multirow{4}{*}{0.96} & \multirow{4}{*}{$0.35-3.26$} \\
\hline $41-50$ & $17(42)$ & $36(33)$ & & \\
\hline $51-60$ & $12(28)$ & $37(35)$ & & \\
\hline$>60$ & $7(15)$ & 19(17) & & \\
\hline Total & $42(100)$ & 108(100) & - & - \\
\hline \multicolumn{5}{|c|}{$\begin{array}{l}\text { Table 1: Distribution of Diabetic Patients (With or } \\
\text { Without Diabetic Retinopathy) According to Age Group }\end{array}$} \\
\hline
\end{tabular}

*For calculation of odds' ratio age groups were clubbed as less than equal to 40 and more than 40 years.

$+\chi 2(1)=0.01 \mathrm{p}=0.93$ (Statistically insignificant)

\begin{tabular}{|c|c|c|c|c|}
\hline \multirow{2}{*}{ Sex } & \multicolumn{2}{|c|}{$\begin{array}{c}\text { Diabetic } \\
\text { Retinopathy }\end{array}$} & \multirow{2}{*}{$\begin{array}{c}\text { Crude } \\
\text { Odds' } \\
\text { Ratio }\end{array}$} & $\begin{array}{c}\text { 95\% } \\
\text { Confidence } \\
\text { Interval }\end{array}$ \\
\cline { 2 - 3 } & Absent & Present & & \\
\cline { 2 - 3 } Ma. (\%) & No. (\%) & & $1.35-6.70$ \\
\hline Female & $16(38)$ & $70(65)$ & 2.99 & - \\
\hline Total & $26(62)$ & $38(35)$ & $1.00(\mathrm{ref})$ & - \\
\hline \multicolumn{3}{|c|}{ Table 2: Distribution of Diabetic Patients (with or } \\
Without Retinopathy) According to Sex
\end{tabular}

${ }^{*} \chi 2(1)=8.83 \mathrm{p}=0.002$ (Highly significant)

\begin{tabular}{|c|c|c|}
\hline \multirow{2}{*}{$\begin{array}{c}\text { Duration } \\
\text { (In years) }\end{array}$} & \multicolumn{2}{|c|}{$\begin{array}{c}\text { Diabetic } \\
\text { Retinopathy }\end{array}$} \\
\cline { 2 - 3 } & Absent & Present \\
\cline { 2 - 3 } & No. (\%) & No. (\%) \\
\hline $0-5$ & $42(100)$ & - \\
\hline $6-11$ & - & $22(20)$ \\
\hline $12-21$ & - & $73(68)$ \\
\hline$>21$ & - & $13(12)$ \\
\hline Total & $\mathbf{4 2 ( 1 0 0 )}$ & $\mathbf{1 0 8 ( 1 0 0 )}$ \\
\hline \multicolumn{2}{|c|}{ Table 3: Distribution of Diabetic Patients } \\
(With or Without Retinopathy) According to \\
Duration of Diabetes in Years \\
\hline
\end{tabular}

${ }^{*} \chi 2(1)=34.12,0 \mathrm{R}=$ undefined

$\mathrm{p}$-value $=0.000$ (Highly significant)

\begin{tabular}{|c|c|c|c|c|}
\hline \multirow{3}{*}{$\begin{array}{l}\text { IOP } \\
(\mathrm{mm} \\
\mathrm{Hg})\end{array}$} & \multicolumn{2}{|c|}{$\begin{array}{c}\text { Diabetic } \\
\text { Retinopathy }\end{array}$} & \multirow{3}{*}{$\begin{array}{l}\text { Crude } \\
\text { Odds } \\
\text { Ratio }\end{array}$} & \multirow{3}{*}{$\begin{array}{l}95 \% \\
\text { Confidence } \\
\text { Interval }\end{array}$} \\
\hline & Absent & Present & & \\
\hline & No. (\%) & No. (\%) & & \\
\hline $10-15$ & $11(27)$ & $36(33)$ & \multirow{2}{*}{1.00 (ref) } & \multirow[b]{2}{*}{-} \\
\hline $16-20$ & $25(59)$ & $61(57)$ & & \\
\hline$>20$ & $6(14)$ & 11(10) & 1.47 & $0.44-4.73$ \\
\hline Total & $42(100)$ & $108(100)$ & - & - \\
\hline \multicolumn{5}{|c|}{$\begin{array}{l}\text { Table 4: Distribution of Diabetic Patients (With or Without } \\
\text { Retinopathy) According to Measurement of IOP } \\
\text { (Intraocular Pressure) with NCT (Non-Contact Tonometer) }\end{array}$} \\
\hline
\end{tabular}

*P-value with Fischer exact test $=0.56$

\begin{tabular}{|c|c|c|c|c|}
\hline \multirow{3}{*}{$\begin{array}{c}\text { Type of } \\
\text { Diabetes }\end{array}$} & \multicolumn{2}{|c|}{$\begin{array}{c}\text { Diabetic } \\
\text { Retinopathy }\end{array}$} & \multirow{3}{*}{$\begin{array}{l}\text { Crude } \\
\text { Odds' } \\
\text { Ratio }\end{array}$} & \multirow{3}{*}{$\begin{array}{l}95 \% \\
\text { Confidence } \\
\text { Interval }\end{array}$} \\
\hline & Absent & Present & & \\
\hline & No. (\%) & No. (\%) & & \\
\hline Type I & 2 & 11(10) & \multirow{2}{*}{\multicolumn{2}{|c|}{ undefined }} \\
\hline Type II & $42(100)$ & $97(90)$ & & \\
\hline Total & $42(100)$ & $108(100)$ & - & - \\
\hline \multicolumn{5}{|c|}{$\begin{array}{l}\text { Table 5: Distribution of Diabetic Patients } \\
\text { (With or Without Retinopathy) According to } \\
\text { Type of Diabetes (Type I or Type II) }\end{array}$} \\
\hline
\end{tabular}

${ }^{*}$ p-value with Fischer exact test $=0.03,0 R=$ undefined

\begin{tabular}{|c|c|c|c|c|}
\hline \multirow{3}{*}{$\begin{array}{c}\text { Blood } \\
\text { Glucose } \\
\text { Levels } \\
\text { (Fasting) } \\
\text { mg \%) }\end{array}$} & \multicolumn{2}{|c|}{$\begin{array}{c}\text { Diabetic } \\
\text { Retinopathy }\end{array}$} & \multirow{3}{*}{$\begin{array}{l}\text { Crude } \\
\text { Odds' } \\
\text { Ratio }\end{array}$} & \multirow{3}{*}{$\begin{array}{c}95 \% \\
\text { Confidence } \\
\text { Interval }\end{array}$} \\
\hline & Absent & Present & & \\
\hline & No. (\%) & No. (\%) & & \\
\hline$<126$ & $35(86)$ & $29(27)$ & 1.00 (ref) & - \\
\hline$>126$ & $7(14)$ & $79(73)$ & 13.62 & $5.07-38.09$ \\
\hline Total & $42(100)$ & $108(100)$ & - & - \\
\hline
\end{tabular}

${ }^{*} \chi 2(1)=39.44,0 \mathrm{R}=13.62 \mathrm{p}$-value=0.0001 (Highly significant)

\begin{tabular}{|c|c|c|c|c|}
\hline \multirow{3}{*}{$\begin{array}{l}\text { Associated } \\
\text { Hypertension }\end{array}$} & \multicolumn{2}{|c|}{$\begin{array}{c}\text { Diabetic } \\
\text { Retinopathy }\end{array}$} & \multirow{3}{*}{$\begin{array}{l}\text { Crude } \\
\text { Odds' } \\
\text { Ratio }\end{array}$} & \multirow{3}{*}{$\begin{array}{c}95 \% \text { Con } \\
\text { fidence } \\
\text { Interval }\end{array}$} \\
\hline & Absent & Present & & \\
\hline & No. (\%) & No. (\%) & & \\
\hline Absent & $31(81)$ & $73(68)$ & 1.00 (ref) & - \\
\hline Present & 11(29) & $35(32)$ & 1.35 & $0.57-3.25$ \\
\hline Total & $42(100)$ & $108(100)$ & - & - \\
\hline \multicolumn{5}{|c|}{$\begin{array}{c}\text { Table 7: Distribution of Diabetic Patients (With or Without } \\
\text { Retinopathy) According to Presence of Associated Hypertension }\end{array}$} \\
\hline
\end{tabular}

${ }^{*} \chi 2(1)=0.55$ p-value $=0.45$ (Not significant)

\begin{tabular}{|c|c|c|}
\hline \multirow{2}{*}{$\begin{array}{c}\text { Altered Renal } \\
\text { Function }\end{array}$} & \multicolumn{2}{|c|}{$\begin{array}{c}\text { Diabetic } \\
\text { Retinopathy }\end{array}$} \\
\cline { 2 - 3 } & Absent & Present \\
\cline { 2 - 3 } & No. (\%) & No. (\%) \\
\hline Unaltered & $42(100)$ & $24(78)$ \\
\hline Altered & - & $\mathbf{1 0 8 ( 1 0 0 )}$ \\
\hline Total & 42(100) & $\begin{array}{c}\text { Retinopathy) According to Presence of } \\
\text { Associated Altered Renal Function }\end{array}$ \\
\hline Table 8: Distribution of Diabetic Patients (With or Without \\
* $\chi 2(1)=11.11,0 \mathrm{R}=$ undefined p-value $=0.0008$ \\
(Highly significant)
\end{tabular}

\begin{tabular}{|c|c|c|c|c|}
\hline \multirow{2}{*}{$\begin{array}{c}\text { Altered } \\
\text { Lipid } \\
\text { Profile }\end{array}$} & $\begin{array}{c}\text { Diabetic } \\
\text { Retinopathy }\end{array}$ & \multirow{2}{*}{$\begin{array}{c}\text { Crude } \\
\text { Odds' } \\
\text { Ratio }\end{array}$} & $\begin{array}{c}\text { 和 } \\
\text { Confidence } \\
\text { Interval }\end{array}$ \\
\cline { 2 - 4 } & Absent & Present & \\
\cline { 2 - 3 } & No.(\%) & No.(\%) & & - \\
\hline Unaltered & $35(86)$ & $79(73)$ & $1.00(\mathrm{ref})$ & $0.68-5.11$ \\
\hline Altered & $7(14)$ & $29(27)$ & 1.84 & - \\
\hline Total & $\mathbf{4 2 ( 1 0 0 )}$ & $\mathbf{1 0 8 ( 1 0 0 )}$ & - & - \\
\hline $\begin{array}{c}\text { Table 9: Distribution of Diabetic Patients (With or Without } \\
\text { Retinopathy) According to Presence of Altered Lipid Profile }\end{array}$ \\
\hline
\end{tabular}

${ }^{*} \chi 2(1)=1.272$ p-value $=0.18$ (Not significant) 


\begin{tabular}{|c|c|c|c|}
\hline \multirow{2}{*}{$\begin{array}{c}\text { Duration of } \\
\text { Diabetes (In years) }\end{array}$} & \multicolumn{3}{c|}{$\begin{array}{c}\text { Diabetic } \\
\text { Retinopathy }\end{array}$} \\
\cline { 2 - 4 } & NPDR & PDR & Maculopathy \\
\cline { 2 - 4 } & No. (\%) & No. (\%) & No. (\%) \\
\hline $\mathbf{0}$ to 5 & - & - & - \\
\hline $\mathbf{6}$ to 11 & $20(22)$ & - & $2(18 \%)$ \\
\hline $\mathbf{1 2}$ to 21 & $67(75)$ & $4(50)$ & $2(18 \%)$ \\
\hline $\mathbf{2 1 1}$ & $2(2)$ & $4(50)$ & $7(64 \%)$ \\
\hline Total & $\mathbf{8 9}(100)$ & $\mathbf{8}(100)$ & $\mathbf{1 1 ( 1 0 0 )}$ \\
\hline $\begin{array}{r}\text { Table 10: Distribution of NPDR (Non-Proliferative Diabetic Retinopathy), PDR (Proliferative Diabetic } \\
\text { Retinopathy) and Maculopathy among Diabetic Retinopathy Patients according to Duration of Diabetes }\end{array}$ \\
\hline
\end{tabular}

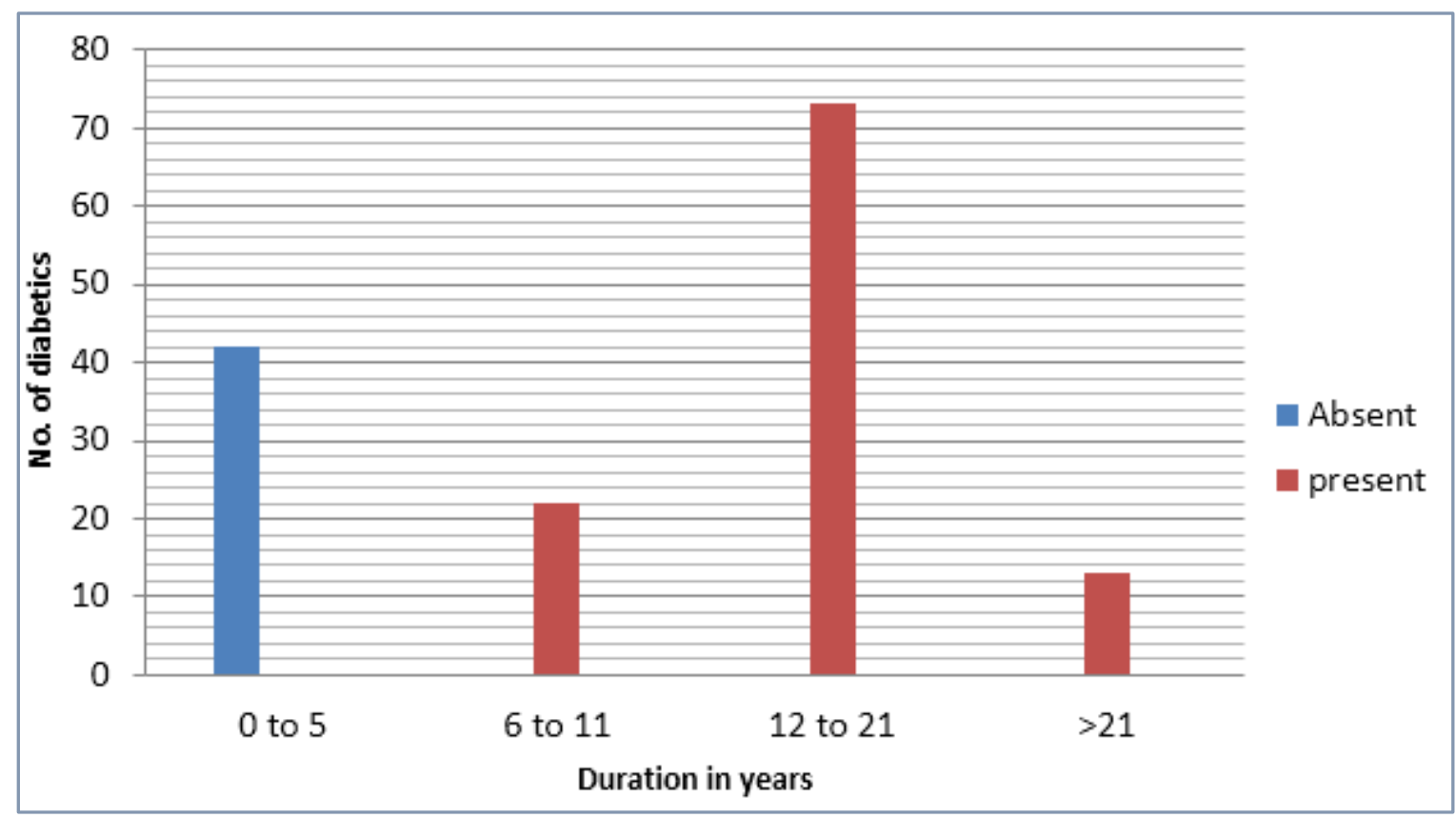

Fig. 1: Distribution of Diabetics with Absent or

Present Retinopathy according to Duration

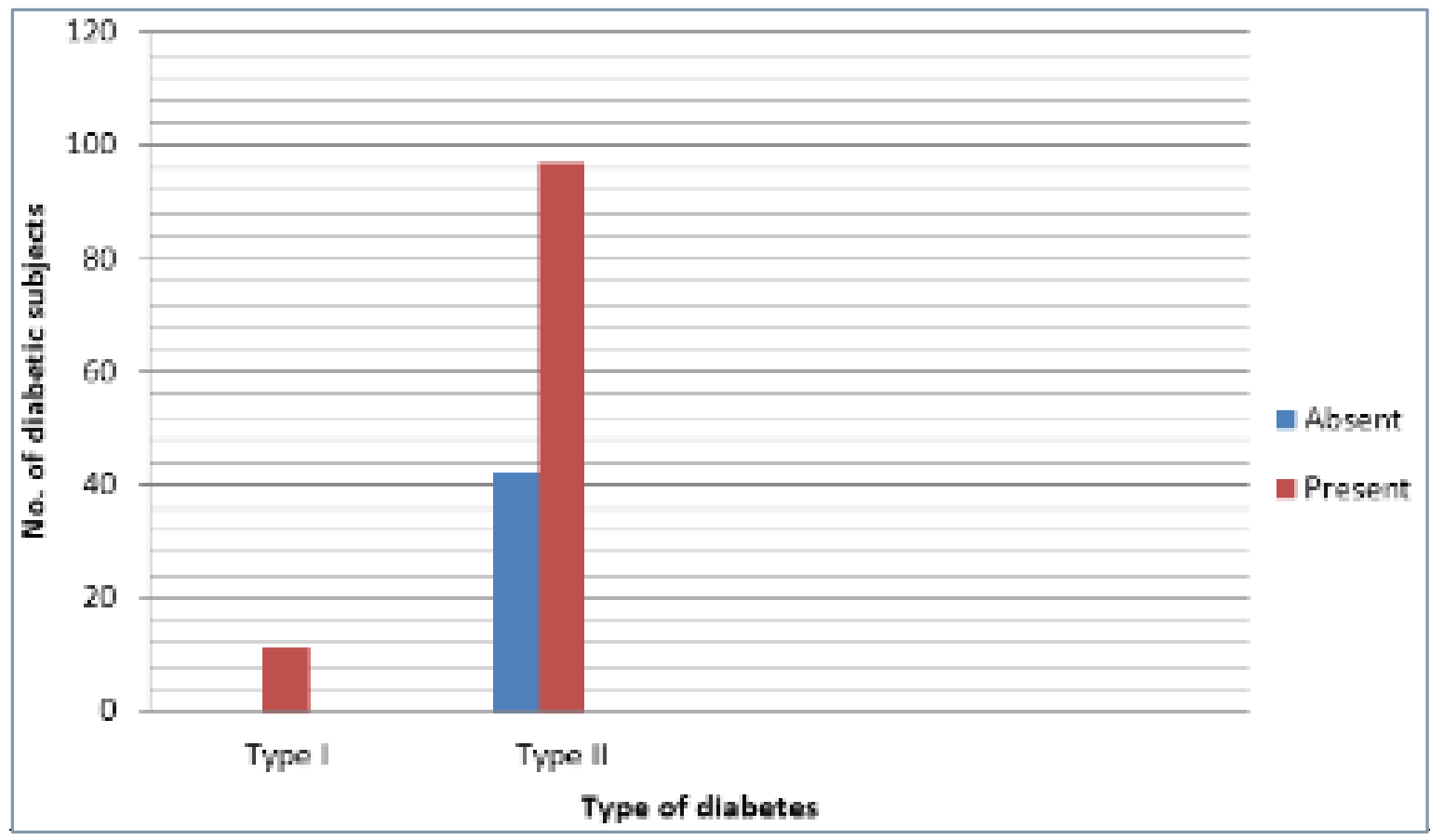

Fig. 2: Distribution of Diabetics with Present or Absent Retinopathy according to Type of Diabetes 


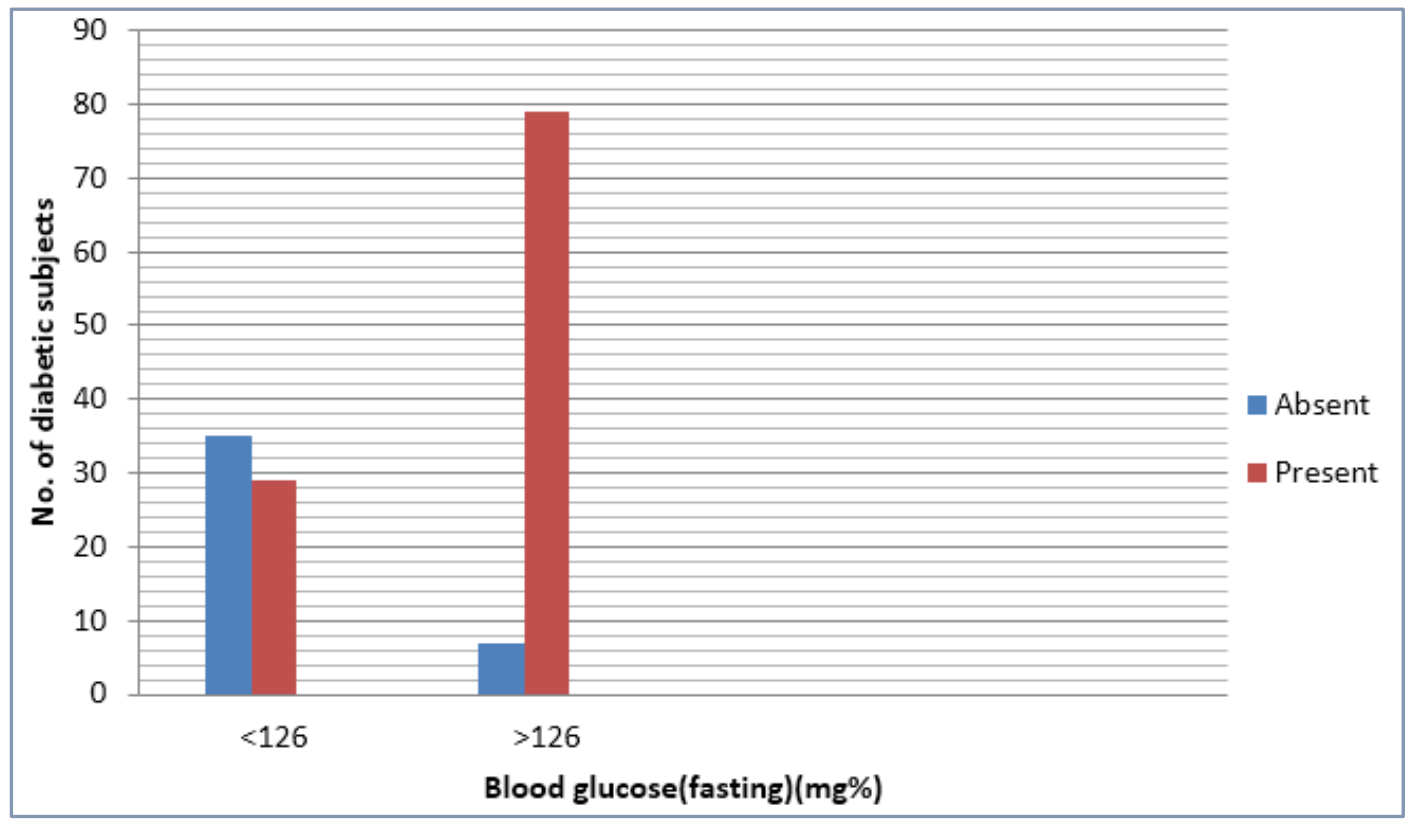

Fig. 3: Distribution of Diabetics with Absent or Present Retinopathy according to Fasting Blood Glucose

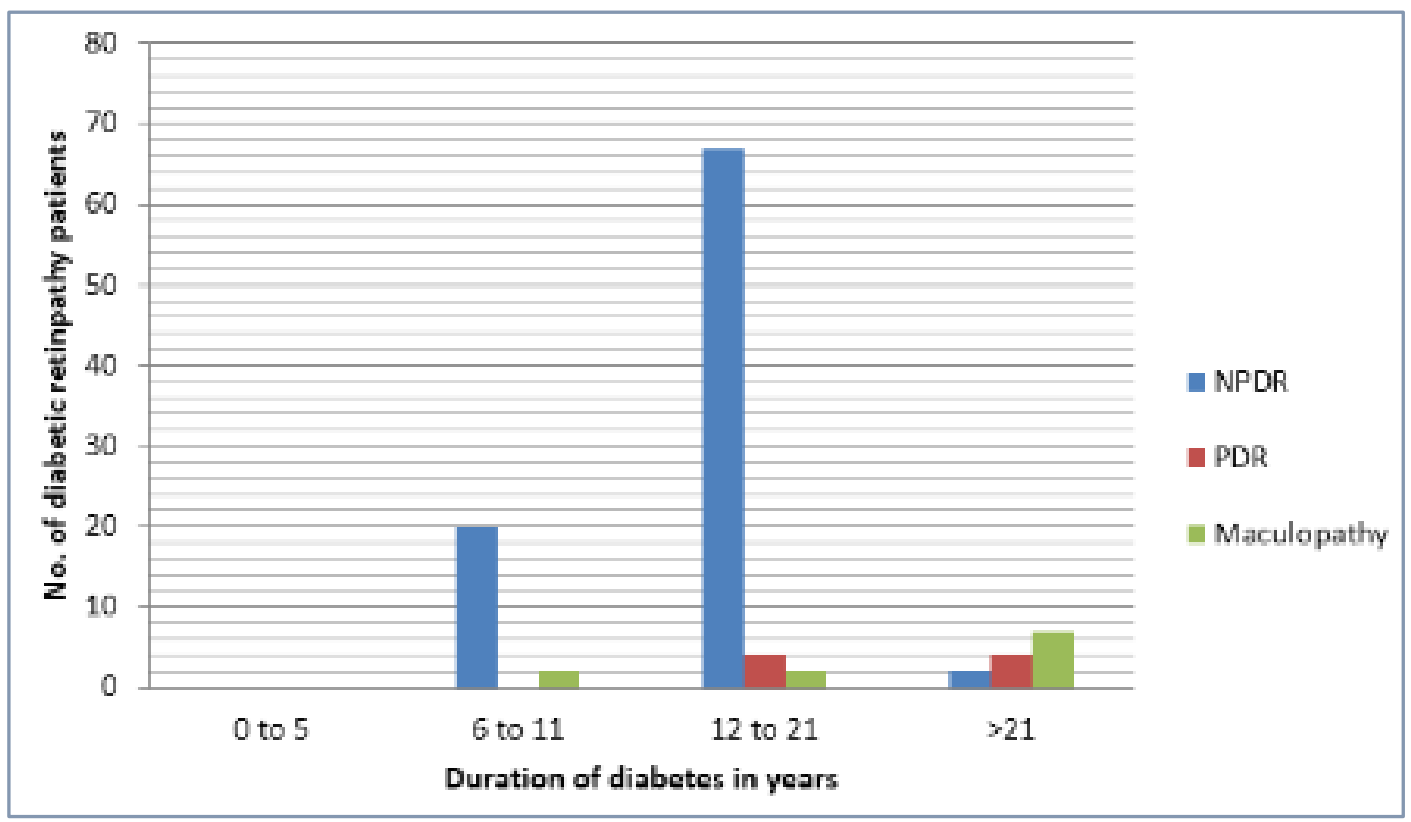

Fig. 4: Distribution of Retinopathy Patients (NPDR, PDR and Maculopathy) according to Duration of Diabetes 